Stanistaw Jankowski*

Aleksandrów Kujawski

\title{
Przebaczenie w Biblii
}

Nie będzie zbytnią przesadą określenie Pisma Świętego jako historii winy i przebaczenia. Bo też śledząc antologie wypowiedzi o tych dwóch pojęciach, łatwo zauważyć, że narracja biblijna to jak gdyby ilustracja tej rozległej problematyki. Z jednej strony potężny chór unisono o człowieku jako istocie grzesznej, ofierze winy, poddanej karze na mocy odwiecznych wyroków Przeznaczenia, z drugiej zaś partia solo w partyturze tekstu natchnionego, do której sporadyczne dołączają świadectwa naturalnej nadziei przebaczenia. Te ludzkie głosy, od głębokiej starożytności często ledwo dosłyszalne, są najbardziej przejmującym potwierdzeniem potrzeby przebaczenia winy. Jak wygląda przebaczenie w Biblii? Na czym polega? Dzięki czemu jest możliwe? Pod jakimi warunkami winowajca może go dostapić? W tym artykule zajmiemy się przebaczeniem w trzech aspektach tej fundamentalnej prawdy: (1) przedstawimy winę, na tle której przebaczenie się objawia, (2) jej wyznanie jako warunek przebaczenia i (3) przebaczenie jako przymiot Boga bogatego w miłosierdzie i jako przykazanie dla człowieka wobec bliźniego.

\section{Wina}

Aby uchwycić biblijną naukę o przebaczeniu, grzechu i winie, należy zauważyć, że zarówno określenie relacji człowieka do Boga, a także

* Ks. dr Stanisław Jankowski SDB jest emerytowanym wykładowcą w Wydziale Teologicznym Uniwersytetu Mikołaja Kopernika w Toruniu. Adres: Kolegium Kujawskie, Chopina 24, 87-700 Aleksandrów Kujawski; e-mail: stanjanko@gmail.com. 
do drugiego człowieka, jak i słownictwo, którym Biblia się posługuje dla wyrażenia tej nauki, zostało zaczerpnięte z międzyludzkich relacji wierzyciel-dłużnik. Realia materialne pomagają uchwycić istotę problemu, rzutują na odniesienia typu duchowego pomiędzy człowiekiem, zaciagającym dług i wierzycielem - Bogiem, a także drugim człowiekiem.

O tym, że grzech, wina jest jednym $\mathrm{z}$ bogatych nurtów myśli biblijnej, świadczy to, iż około 35 różnych terminów składa się na kategorię grzechu/ winy (w greckim NT 20). Można je podzielić na kilka grup. Jedna z nich obejmuje to wszystko, co jest przejawem kondycji stworzenia, a więc niedoskonałość, zawodność, ułomność, błądzenie, nietrafne wnioskowanie. Kohelet określa tę cechę stworzenia ogólnym pojęciem „marność”, podczas gdy w innych tradycjach spotykamy określenie „ciało". Druga grupa obejmuje winy zaciągnięte świadomie i dobrowolnie pod wpływem namiętności i nieuporządkowanych pragnień, potocznie nazywanych pokusą. Tego rodzaju winę zaciaga się, ulegając - wbrew sumieniu i prawu - sugestiom i obietnicom korzyści różnego typu, jest więc skutkiem dążeń, decyzji i działań niezgodnych z ustalonym przez Boga porządkiem. Wreszcie trzecia grupa to czyny popełnione pod wpływem buntu, nienawiści i woli wyrządzania krzywdy Bogu i Jego stworzeniom. Już nie odgrywa w tym przypadku roli ewentualna korzyć, lecz satysfakcja z robienia „na złość”, wyrządzenia szkody. Zaliczyć tu należy winy spowodowane ideologiami ateistycznymi i demoralizatorskimi, walką z Bogiem, które usprawiedliwiają przemoc, zniewolenie, zgorszenie i zbrojne konflikty, dążą do narzucenia ludziom porządku alternatywnego w stosunku do tego, jaki człowiek odczytuje w swoim sumieniu (oczywiście chodzi o sumienie, które nie uległo deprawacji), w prawie natury i w Objawieniu. Mówiąc o winie w Biblii, należy tu przywołać tradycję Janową, która mówi jeszcze o grzechu par excellence, który Syn Boży jako Baranek przyszedł zgładzić (zob. J 1, 29; por. Ap 5, 6. 12 i in.). Co nim jest? Pierwszy List św. Jana mówi o tajemniczej winie, która nie będzie odpuszczona; za winnego takiego grzechu, sprowadzającego śmierć, autor nie poleca się modlić (1 J 5, 16). Dość powszechna jest opinia, że chodzi o grzech przeciw Duchowi Świętemu, czyli taki, który uniemożliwia Bogu przebaczenie jego sprawcy (zob. Mt 12, 31 i n.; 1 J 2, 18-29; Hbr 6, 4-8).

Wina powoduje lęk, winowajca ucieka i usiłuje ukryć swoje złe czyny jak Adam². W następstwie przewodu sądowego (hebr. rib), jaki Bóg prze-

${ }^{1} \mathrm{~W}$ teologii moralnej nazywa się tę kategorię jako grzechy lekkie, peccata venialia.

${ }^{2} \mathrm{Rdz}$ 3, 7 i n. doskonały kazus dla psychoanalizy: najpierw Adam i Ewa sporządzili 
prowadził wobec pierwszych winowajców, spotkały ich jako kara smutek, cierpienie i usunięcie z Edenu - Ogrodu Szczęścia (Rdz 3, 8-19). Wszystkie inne przestępstwa będą czerpały z winy Adama i Ewy wzorce i schematy jak zatrute soki. Wszystkie je można sprowadzić do wspólnego mianownika istota winy sprowadza się do nieposłuszeństwa wobec Stwórcy, polega na przekroczeniu Jego woli wyrażonej w przykazaniach i w jeszcze większym stopniu na niewierności przymierzu, jakie Bóg zawarł z człowiekiem na dowód swej życzliwości. Treść tego przymierza człowiek odczytuje w sumieniu jako prawo naturalne.

W antropologii biblijnej, charakteryzującej się trzeźwą oceną, nie brak dozy pesymizmu. Wyrażenie: „usposobienie człowieka jest złe już od młodości” (Rdz 8, 21), potwierdza spostrzeżenie Księgi Przysłów, że „w sercu chłopięcym głupota się mieści”, to znaczy, że skłonność do nieuporządkowanych wyborów i działań jest człowiekowi wrodzona i ujawnia się od młodości $($ Prz 22, 15)3 . Jednak nie można nie pamiętać o wyznaniu św. Pawła, który idzie jeszcze dalej w swoim dopowiedzeniu do realistycznego stwierdzenia z Księgi Rodzaju: ,jestem cielesny, zaprzedany w niewolę grzechu. Nie rozumiem bowiem tego, co czynię, bo nie czynię tego, co chcę, ale to, czego nienawidzę - to właśnie czynię”. I dalej: „Nie czynię bowiem dobra, którego chcę, ale właśnie zło, którego nie chcę"4. Wreszcie konkluduje swoje rozterki: „W członkach zaś moich spostrzegam prawo inne, które toczy walkę z prawem mojego umysłu i bierze mnie w niewolę pod prawo grzechu mieszkającego w moich członkach. Nieszczęsny ja człowiek! Któż mnie wyzwoli z ciała, [co wiedzie ku] tej śmierci?” (Rz 7, 14-15. 19. 23-24). Rozwiązanie swoich rozterek Paweł znajduje w tajemniczym planie Boga: Bóg poddał wszystko „marności”, aby wszystkiemu objawić miłosierdzie, to znaczy ofiarować przebaczenie dyktowane miłością (zob. Rz 5, 8; 8, 20-21; Mdr 11, 23-26).

sobie przepaski, aby ukryć nagość - symbol wstydu, później ukryli się przed Bogiem, w którym teraz widzieli sędziego, wreszcie próbowali Boga okłamać (zob. Rdz 3, 7 i n.). Nota bene pierwotna nagość oznacza niczym nie niepokojoną transparentność, prawdę, czytelność, światło postawy i czynów. Jak dochodzi do grzechu, przedstawił Waldemar Chrostowski w artykule „Anatomia pokusy (Rdz 3, 1-6)”, Przeglad Powszechny 5 (1984), 198-207 ukazał mechanizm, jaki Wąż uruchamia, żeby doprowadzić człowieka do grzechu. W opisie pierwszego grzechu został ukazany archetyp wszystkich ludzkich grzechów.

${ }^{3} \mathrm{~W}$ tradycji rabinackiej znane jest pojęcie yetser ha-ra $(\mathrm{J})$ - zła pożądliwość, zob. The Oxford Dictionary of the Jewish Religion, red. R. J. Zwi Werblowsky, Geoffrey Wigoder (New York: Oxford University Press, 1997), 742-743.

4 Te słowa św. Pawła to jakby echo wyznania Owidiusza: „Video meliora proboque, deteriora sequor", w: Metamorfozy, VII, 20. 
Analizując teksty biblijne od strony przedstawianej w nich winy, nie można im odmówić wnikliwości i realizmu. Ostatecznie u podłoża kondycji stworzenia - jak zostało to ukazane wcześniej - według Objawienia kryje się jednak nadzieja wyzwolenia, zapowiedziana w obrazie niewiasty i jej potomka, który zetrze głowę węża i przyniesie ludziom zbawienie ( $\operatorname{Rdz} 3$, 15). Przebaczenie wszakże może mieć miejsce pod warunkiem, iż stworzenie uzna swoją „marność” i wyzna swoją winę w duchu miłości i w świetle prawdy.

\section{Prawda drogą do przebaczenia}

Droga do przebaczenia prowadzi przez prawdę, w której Bóg ma upodobanie (Ps 51, 8), brzydzi się natomiast kłamstwem. Aby mogło nastąpić wyznanie, musi najpierw mieć miejsce uznanie popełnionego zła. U podstaw biblijnej nauki o przebaczeniu znajduje się bowiem wymóg prawdy. Nie ma przebaczenia bez wyznania prawdy o popełnionym grzechu.

Tym, co definiuje relację człowieka z Bogiem, jest właśnie prawda. Co to jest prawda? Otóż według Objawienia prawda to nie tyle zgodność słowa $\mathrm{z}$ rzeczywistością, jak chce filozofia, ale to Osoba! Według Objawienia to sam Bóg jest Prawdą i konsekwentnie wszystko, co od Niego pochodzi, a więc Jego przykazania są prawdą (Ps 119, 151), Jego Prawo jest prawdą (w. 142). Prawda jest podstawą Jego słowa (w. 160). Na innym miejscu mówi tekst natchniony, że Jego słowa są prawdą (zob. $2 \mathrm{Sm} 7,28)^{5}$. Wśród rozlicznych cech prawdy, które trudno byłoby w tym miejscu omówić ${ }^{6}$, szczególnie rzuca się w oczy jej niezmienność, fundamentalna trwałość, porównanie do niewzruszonej skały. U Boga nie ma równocześnie „tak” i „nie”, podobnie i u Jego Syna, który z Ojcem stanowi jedno (J 10, 30). Święty Paweł głosi

${ }^{5}$ Dokument Papieskiej Komisji Biblijnej, Natchnienie i prawda Pisma Świętego. Słowo, które od Boga pochodzi i mówi o Bogu, aby zbawić świat, tłum. H. Witczyk (Kielce: Verbum, 2014), z 22 lutego 2014 r., w nr 64 głosi m.in.: „W Starym Testamencie sam Bóg jest najwyższą prawdą dzięki stałości swoich wyborów, obietnic i darów”. W konsekwencji ,jego słowa są wiarygodne i wymagają podobnej stałości w przyjęciu i w odpowiedzi człowieka, w jego sercu i w czynach (por. np. $2 \mathrm{Sm} 7,28$ i Ps 31, 6). (...) W Nowym Testamencie Chrystus jest prawdą" (s. 110, zob. s. 111).

${ }^{6}$ Aby zorientować się o treści terminu ,prawda“ w Biblii, wystarczy chociażby konsultacja haseł w słownikach biblijnych, np. Ignace de la Potterie, „Prawda”, w: Stownik teologii biblijnej, red. Xavier Léon-Dufour (Poznań: Pallottinum, 1973), 763-768. Nota bene nasza odpowiedź, kiedy przyjmujemy Komunię świętą: „Amen”, znaczy: „To prawda”, „Tak jest”. 
uroczyście: „Syn Boży, Jezus Chrystus, (...) nie był »tak« i »nie«, lecz dokonało się w Nim »tak». Albowiem ile jest obietnic Bożych, w Nim wszystkie są »tak«" (2 Kor 1, 19-20). Wreszcie od Chrystusa w Ewangelii św. Jana słyszymy: „Prawda was wyzwoli” (J 8, 32). Można to wyrażenie rozumieć na różne sposoby, ale narzucają się tu dwa: powszechnie jest znane uczucie ulgi po wyznaniu prawdy, nie mówiąc o ,spowiedziach” przed drugim człowiekiem z własnych porażek, błędów, nie wyłączając zbrodni, ale też w znaczeniu teologicznym: wyzwala prawda, którą jest Jezus, Syn Boga i Jego Słowo (J 14, 6; por. 17, 17).

W biblijnej nauce o przebaczeniu istotny jest wymóg, aby winny/grzesznik sam siebie oskarżył, to znaczy, aby wyznał, że słuszność jest po stronie Boga pokrzywdzonego grzechem/winą człowieka. Klasycznym przykładem ilustrującym ten typ wyznania, na kształt przewodu sądowego, jest historia Akana, który popełnił grzech świętokradztwa podczas wojny świętej, ponieważ przywłaszczył sobie przedmioty obłożone klątwą (hebr. herem). Jozue zwrócił się do niego: „Synu mój, daj chwałę Panu, Bogu Izraela i złóż przed Nim wyznanie. Powiedz mi: Coś uczynił? Nic nie ukrywaj przede mną". Wówczas Akan wyznał prawdę: „Istotnie zgrzeszyłem przeciw Panu, Bogu Izraela”. I opisał swój czyn oraz gdzie ukrył zawłaszczone świętokradczo przedmioty. Za ten grzech spotkała go surowa kara, jak również jego rodzinę: on sam został ukamienowany, a jego rodzina spalona (zob. Joz 7) ${ }^{7}$. Inny przypadek winy osobistej: król Dawid, ,przyparty do muru” oskarżeniem proroka Natana, kiedy ten wypomniał królowi dwie zbrodnie i próbę ich ukrycia, wyznał: „Zgrzeszyłem przeciw Bogu”. W odpowiedzi prorok zapewnia króla, że Bóg mu te winy odpuszcza, wszak będzie musiał ponieść skutki popełnionych zbrodni (zob. 2 Sm 11-12). Przyznanie się do prawdy skutkowało darowaniem winy Dawidowi. Ktoś później sięgnął po ten epizod z życia Dawida i włożył w usta króla grzesznika Psalm 51.

W Starym Testamencie spotkamy wiele wyznań pokutnych, jak chociażby wyznanie Ezdrasza (zob. Ezdr 9, 6-15), Nehemiasza (Ne 9, 5-37) czy modlitwę Azariasza w piecu ognistym: „Tak, zgrzeszyliśmy i popełniliśmy nieprawości, / opuszczając Ciebie. / Okazaliśmy się przewrotni we wszystkim, / a przykazań Twoich nie słuchaliśmy. / Nie zachowaliśmy ani nie wypełniliśmy / tego, co nam nakazałeś, / by się nam dobrze wiodło" (Dn 3, 29-30). Nie możemy pominąć Księgi Psalmów, zwłaszcza grupy psal-

${ }^{7}$ Grzech w Biblii ma charakter społeczny, „promieniuje” najpierw na najbliższych, ale dotyka także ziemi, zwierząt i ogólnie całego stworzenia. Wszak mówienie tu o odpowiedzialności zbiorowej jest dużym skrótem myślowym i uproszczeniem. 
mów zwanej Psalmami pokutnymi (Ps 6; 32; 38; 51; 102; 130; 145), gdzie motyw wyznania win bardzo często się przewija. Podobnie w znanej przypowieści o miłosiernym ojcu i marnotrawnym synu, gdzie ten ostatni wyznaje: „Ojcze, zgrzeszyłem przeciw Niebu i wobec ciebie, już nie jestem godzien nazywać się twoim synem" (Łk 15, 18. 21). Teksty, jak ten, charakteryzuje niezwykła emanacja nie tylko bólu, rozterki, ale i ufności, bo nie miałoby sensu wyznanie, nawet najgorętsze, gdyby nie istniała nadzieja wysłychania i przebaczenia. Są to też teksty o uderzającej introspekcji, nieoszczędzające miłości własnej grzesznika. Dowodza, że tylko przez wyznanie popełnionych win można dostąpić Bożego przebaczenia.

$\mathrm{Na}$ antypodach postawy skruchy i wyznania teksty biblijne ukazują postawę arogancji, cynizmu i zadufania. Będzie to najpierw Kain, który na pytanie Boga: „Gdzie jest brat twój, Abel?”, odpowiada z całą bezczelnością: „Nie wiem. Czy jestem stróżem brata mego?”, a potem „narzeka”: „Zbyt wielka jest kara moja, abym mógł ją znieść" (Rdz 4, 9. 13). Syrach ze swojej strony przestrzega:

Nie mów: „Zgrzeszyłem i cóż mi się stało?” Albowiem Pan jest cierpliwy. Nie bądź tak pewny darowania ci win, byś miał dodawać grzech do grzechu. Nie mów: „Jego miłosierdzie zgładzi mnóstwo moich grzechów”. U Niego jest miłosierdzie, ale i zapalczywość, a na grzeszników spadnie Jego gniew karzący. Nie zwlekaj z nawróceniem do Pana ani nie odkładaj tego z dnia na dzień: nagle bowiem gniew Jego przyjdzie i zginiesz w dniu wymiaru sprawiedliwości (Syr 5, 4-7).

Próba okłamania Boga i wspólnoty ludu Bożego skończyła się tragicznie zarówno dla dwóch starców w historii Zuzanny (zob. Dn 13), jak i dla Ananiasza oraz Safiry w dziejach młodego Kościoła jerozolimskiego (zob. Dz 5, 1-11).

Wiara $\mathrm{w}$ przebaczenie rodzi nadzieję nieocenionego dobra w postaci pojednania, a to z kolei przywraca pogodę ducha, pokój, ufność, że relacje $\mathrm{z}$ pokrzywdzonym staną się takie jak przed popełnionym grzechem czy wyrządzoną krzywdą (każda krzywda jest grzechem, chociaż aspekty mogą być różne). Nic dziwnego, że wyznający Bogu swoją winę Dawid z Psalmu 51 prosi właśnie o te dary jako dopełnienie przebaczenia: „Spraw, abym usłyszał radość i wesele, / niech się radują kości, któreś skruszył”, i dalej: „Stwórz, o Boże, we mnie serce czyste / i odnów w mojej piersi ducha niezwyciężonego! (...) Przywróć mi radość z Twojego zbawienia / i wzmocnij mnie duchem ochoczym!" (ww. 10. 12. 14). Potwierdzeń tej pewności przebaczenia płynącej z wiary objawionej pełne są stronnice obu Testamentów. 


\section{Przebaczenie}

Miłosierdzie jako atrybut Boga stało się w naszych czasach popularne dzięki encyklice Jana Pawła II Dives in misericordia (30.11.1980). Papież „Z rodu Słowian” odkrył bogactwo treści tego przymiotu, który jest - jak głosi z kolei Koran - pierwszym z dziewięćdziesięciu dziewięciu imion Allaha ${ }^{8}$. Przebaczenie (hebr. kapper, gr. aphesis) ${ }^{9}$ jest możliwe tylko jako skutek miłosierdzia, bliska mu znaczeniem jest wielkoduszność (makrothymia). Między zwyczajnym przebaczeniem i przebaczeniem grzechów jest różnica polegająca na tym, że grzechy może przebaczyć tylko Bóg, podczas gdy człowiek do darowania i przebaczenia win jest wezwany, aby naśladował w tym Boga i żeby to czynił - jak uczy Chrystus - siedemdziesiąt siedem razy, czyli zawsze (zob. Mt 18, 21-22; por. Łk 17, 3-4).

Aby uwypuklić doniosłość przebaczenia, należy najpierw oddać głos sprawiedliwości. W każdym człowieku, który ma jakieś poczucie sprawiedliwości, dochodzi ona do głosu, kiedy ma miejsce jej naruszenie. Od winowajcy pokrzywdzony zwyczajnie oczekuje naprawienia winy, wyrównania krzywdy, chociażby słowa „przepraszam”. Zwyczajnie bowiem prawo przewiduje karę za karygodny czyn (o zemście tu nie mówimy!). Ale pokrzywdzony może też darować winowajcy, po prostu przebaczyć. Taka postawa dowodzi, że miłosierdzie wykracza poza porządek sprawiedliwości, zgodnie z twierdzeniem św. Jakuba: „miłosierdzie odnosi triumf nad sądem" (Jk 2, 13) ${ }^{10}$. Warto tu zwrócić uwagę, że słowa

${ }^{8}$ Nie można utożsamiać treści terminu „miłosierdzie” w Koranie i w Biblii. Są to treści zgoła różne! Wystarczy wywołać w Internecie hasło „Islam i miłosierdzie”, aby mieć możność wglądu w opinie, jak Koran rozumie miłosierdzie.

9 Ideę przebaczenia, odpuszczenia wyraża kilka terminów hebrajskich i greckich. Oddają ważny aspekt zbawczego dzieła Boga przebaczającego: salah - „przebaczyć, rozgrzeszyć”, naśa' - „znieść, usunąć”, kipper (pi el) - „zakryć, przykryć, zapomnieć, nie widzieć”, ga'al - „wykupić“, podobne znaczenie ma padah. LXX oddaje treść hebrajskich słów najczęściej przez aphiemi - „znieść, usunąć”, aniemi - „zostawić, zaniechać”, aphaireo - „znieść, usunąć”, hilaskomai - „okazać się łaskawy, przychylny”; ale też airo - „usuwam, gładzę”, lyo, apolyo - „niszczę, unicestwiam, uwalniam z więzów”, charizomai - „okazuję łaskawość, życzliwość, przychylność". Termin aphesis w NT występuje 16 razy, inne terminy oddające także po części tę samą treść, to eleutheria - „uwolnienie, odpuszczenie”, eleutheros - „uwolniony, rozgrzeszony”, eleutheroo - „uwalniam, odpuszczam”, katargeo - „znosić, unieważnić, niweczyć, odsuwać”, anesis - „ulga, odprężenie”, dikaioo - „usprawiedliwiam, czynię sprawiedliwym, uwalniam”, zob. Remigiusz Popowski, Wielki słownik grecko-polski Nowego Testamentu (Warszawa: Vocatio, 1995), sub voce.

${ }_{10}$ Znane były w średniowieczu i w okresie renesansu spory teologów, czy Bóg jest 
hebrajskie czy greckie oddają zarówno dosłowny, jak i przenośny sens tego pojęcia ${ }^{11}$.

Bóg Izraela, dla chrześcijan Ojciec naszego Pana, Jezusa Chrystusa, jest nazywany Bogiem bogatym w miłosierdzie (Ef 2, 4), przebaczającym grzechy albo jak twierdzi przywołany już św. Jakub: „Pan pełen jest litości i miłosierdzia" (Jk 5, 11; zob. Wj 34, 6; Ps 103, 8; 111, 4). Właściwe Mu są też synonimy miłosierdzia - wielkoduszność (gr. makrothymia) i dobroć (gr. chrestotes) ${ }^{12}$. On nie pamięta naszych grzechów, zakrywa je, wymazuje. Nehemiasz zwraca się do Boga w sposób bardzo bezpośredni: „Lecz Ty jesteś Bogiem przebaczenia, / jesteś łagodny i litościwy, / nieskory do gniewu i bogaty w łaskę” (Ne 9, 17), albo jak autor Ps 86 wyznaje: „Ty bowiem, Panie, jesteś dobry i pełen przebaczenia" (Ps 86, 5; zob. Mdr 6, 6). Syrach zdumiewa się wielkością Bożego przebaczenia: „Jakże wielkie jest miłosierdzie Pana / i przebaczenie dla tych, którzy się do Niego nawracają" (Syr 17, 29). Nowy Testament z perspektywy „pełni czasów” (Ga 4, 4) postrzega Pierwszy Testament jako świadectwo miłosierdzia Boga, który - jak głosi prorok Ozeasz - na samą myśl, że mógłby potraktować swój naród jak Admę czy Seboim (zob. Rdz 19), doznaje głębokiej litości: „Moje serce na to się wzdryga / i rozpalają moje wnętrzności” $(\mathrm{Oz} 11,8)$.

Podobnie Ewangelie, jako zbawcze orędzie Chrystusa, są przepowiadaniem miłosierdzia Ojca wobec grzesznych, błądzących i zbuntowanych synów. On przyszedł ich odnaleźć i wezwać do nawrócenia, rozgrzeszyć i uzdrowić. Jego słowa „pełne mocy” (Łk 4, 32; por. Mk 11, 27) i czyny świadczą, że zbliżyło się królestwo Boże jako eon miłosierdzia. Wreszcie męka stanowi początek, a zarazem apogeum tego wydarzenia, natomiast wołanie Ukrzyżowanego Chrystusa: „Ojcze, przebacz im, bo nie wiedzą, co czynią" (Łk 23, 34), jest jak pieczęć uwierzytelniająca prawdziwość świadectwa Jego życia i słów.

Chociaż w Listach Pawłowych nauka o zbawieniu jest jednym z kluczowych wątków teologicznych, to - jak zauważa Leon Morris - terminy odwołujące się do ,przebaczenia występują u św. Pawła stosunkowo rzadko

bardziej sprawiedliwy, czy miłosierny, a także - jak w ogóle jest możliwe pogodzenie obu tych atrybutów Boga!

${ }^{11}$ Zauważalna różnorodność znaczeń, aczkolwiek bliskich sobie, ukazuje głębię, dynamikę i bogactwo Bożego przebaczenia. Marc Lods, „Pardon”, w: Dictionnaire Encyclopedique de la Bible, red. Pierre-Mourice Bogaert i in. (Turnhout: Brepols, 1987), 967.

${ }^{12}$ NT 14 razy, Listy św. Pawła 10 razy, omówienie zob. Udo Falkenroth, „Makrothymia”, w: Dizionario dei concetti biblilici del Nuovo Testamento, red. Leonard Coenen, Erich Beyreuther, Hans Bietenhard (Bologna, Edizioni Dehonane, 1976), 1228-1230. 
w porównaniu z częstym użyciem terminów określających to, czego dokonał Jezus dla zbawienia wierzących”. Wszak dodaje zaraz, że nie ma przesłanek do twierdzenia, ,że Paweł nie dostrzega znaczenia tego ważnego aspektu chrześcijaństwa, prawdą jest jednak to, że posługuje się nim znacznie rzadziej niż można by się tego spodziewać"13. Według św. Pawła przebaczenie (gr. afiemi, charizomai i in.) ${ }^{14}$ stanowi integralną część soteriologii - nauki o zbawieniu i historii zbawienia, która według niego ma strukturę dialektyczna, czego ilustracją może być teza Pawła, iż gdzie rozpanoszył się grzech za sprawą Adama, tam za sprawą Jezusa Chrystusa jeszcze obficiej rozlała się łaska, a więc również dar przebaczenia (zob. Rz 5, zwłaszcza w. 17). Przebaczenie Paweł podciaga pod stan usprawiedliwienia, które winowajca/ grzesznik otrzymuje w następstwie wiary w Jezusa jako Syna Bożego, którego Ojciec zesłał dla przebłagania za nasze grzechy. W Rz 10 wiara okazana Jesusowi i Jego dziełu owocuje przebaczeniem grzechów, zbawieniem i życiem wiecznym (zob. w. 9-10). Paweł spieszy także z wyłuszczeniem, jak rozumie gniew Boga na popełniane zło. Gniew jest reakcją Boga na grzech, objawia się jako sprzeciw wobec winy człowieka, wszak przejaw tego gniewu jest nieoczekiwany - objawia się według św. Pawła w przebaczeniu, którego poświadczeniem jest poświęcenie się Syna Bożego dla odkupienia świata. On umarł za nasze grzechy, aby wyjednać nam usprawiedliwienie. Przytoczone pojęcia tworzą zwarty splot powiązań skutkujących darem zbawienia. Słowem, przebaczenie to ,strategia” Boga wyrażona w miłosierdziu.

Dzięki temu fundamentowi możemy jako grzesznicy z ufnością wołać: „Odpuść nam nasze winy (długi), bo i my darujemy naszym dłużnikom” (Mt 6, 12; por. 18, 21-22; Ef 4, 32). Wołanie o darowanie win w Modlitwie Pańskiej Chrystus pozwala traktować jako tytuł płynący z faktu, że oto my przebaczamy naszym ,winowajcom”, możemy zatem żywić nadzieję, że i nam Bóg przebaczy. To poniekąd druga strona tej samej nauki, która głosi, że jeżeli nie przebaczymy naszym winowajcom, to i Bóg nie przebaczy nam

13 Leon Morris, „Przebaczenie”, w: Stownik teologii św. Pawła, red. Gerald F. Hawthorne, Ralph P. Martin, Daniel G. Reid (Warszawa: Vocatio, 2010), 661-662.

${ }^{14} \mathrm{Na} 142$ wystąpienia czasownika aphiemi w NT 45 razy oznacza on ,przebaczyć”, w pozostałych przypadkach oznacza „zostawić, uwolnić, odesłać” itp., natomiast rzeczownik aphesis oznacza „przebaczenie”, tylko dwa razy oznacza „wypuszczenie z więzienia”. LXX, a NT za nią, używa też zwrotów opisowych. Święty Paweł dla oddania idei przebaczenia woli posługiwać się takimi pojęciami jak dikaioo - „usprawiedliwić”, dikaiosyne - „sprawiedliwość, usprawiedliwienie”, katallasso - „pojednać”. Zob. H. V. e A. T., „Perdono“, w: Dizionario dei concetti biblilici del Nuovo Testamento, red. Leon Coenen, Erich Beyreuther, Hans Bietenhard (Bologna: Edizioni Dehoniane, 1976), 1272-1275. 
naszych grzechów (Mt 5, 14-15). Tę prawdę ilustruje przypowieść o niemiłosiernym wierzycielu (Mt 18, 23-35), w której Chrystus uwrażliwia na potrzebę kierowania się miłosierdziem, wielkodusznością i przebaczeniem wobec bliźnich, którzy wobec nas zawinili. W tym miejscu może pojawić się pytanie: dlaczego tacy jesteśmy: niedoskonali, zadający ból bliźnim, wyrządzający im krzywdę itd.? W odpowiedzi można pokusić się o twierdzenie, że wprawdzie Bóg stworzył człowieka niedoskonałym, ale jako istotę z perspektywą rozwoju, wzrostu, dochodzenia do dojrzałości, stworzył w ten sposób przestrzeń dla objawienia swego miłosierdzia, a gdy chodzi o nas - także dla pracy nad sobą, w tym dla przebaczania bliźniemu.

Władzą jednania z Bogiem, odpuszczania grzechów i egzorcyzmu Chrystus podzielił się z apostołami. Wybrał ich z myślą, aby byli przedłużeniem Jego misji. Od Jego męki zakończonej śmiercią i triumfem zmartwychwstania teraz oni pełnią tę samą misję: „Jak Ojciec Mnie posłał, tak i Ja was posyłam. (...) Weźmijcie Ducha Świętego! Którym odpuścicie grzechy, są im odpuszczone, którym zatrzymacie, są im zatrzymane" (J 20, 21-23; zob. Mk 2, 1-12). Swój mandat Jezus uzupełnia darem Ducha Świętego; to mocą Jego Ducha będą realizować powierzone im posłannictwo. Misja apostołów w wydaniu Janowym - jak widać - jest przedłużeniem zbawczej posługi Jezusa. Należy do niej władza odpuszczania grzechów, czyli zapewnienia pokutującego grzesznika w imieniu Chrystusa, że Bóg mu jego winę odpuścił ${ }^{15}$. Ten tekst $\mathrm{w}$ Ewangelii Janowej stanowi całość razem z nakazem z Mateuszowowej Dobrej Nowiny: „Idźcie więc i nauczajcie wszystkie narody, udzielając im chrztu w imię Ojca i Syna, i Ducha Świętego" (Mt 28, 19). Odtąd Kościół uzbrojony w moc Ducha będzie udzielał chrztu i odpuszczał grzechy, ciesząc się obecnością swego Założyciela aż do końca świata. Według niektórych autorów - zwłaszcza protestanckich - logion Chrystusa o władzy odpuszczania grzechów danej apostołom można rozumieć też szerzej. Chodziłoby mianowicie nie tylko o władzę sakramentalną, ale i o wymiar duchowy nowej rzeczywistości, która nastała dzięki męce i zmartwychwstaniu Pana. Przebaczenie jest za sprawą swego charakteru i przeznaczenia czynnikiem budującym z pomocą łaski Kościół od wewnątrz na drodze akceptacji Drugiego jako istoty wprawdzie również niedoskonałej, ale Stwórca, który umiłował ludzi odwieczną miłością, chce każdego

15 Rozgrzeszający spowiednik właśnie dzięki sakramentowi kapłaństwa jest i narzędziem, i uczestnikiem w darze przebaczenia, którego dostępuje pokutujący grzesznik, zob. Katechizm Kościoła katolickiego, nr 1448-1449, 1461-1467 (Poznań: Pallottinum, 1994), 346, 349-350. 
widzieć doskonałym na podobieństwo swego Syna (tę doskonałość Syn objawił w przebaczeniu na krzyżu) i jak On sam jest święty, bo przebaczający bez zwłoki, ilekroć człowiek się do Niego zwraca, uznając swoje winy (zob. Lb 19, 2).

\section{Zakończenie}

Przebaczenie w Biblii jest tematem bardzo bogatym w treści. Z jednej strony sięga samych podstaw metafizyki stworzenia poddanego „marności”, a z drugiej dotyka Boga, który w bogactwie swego miłosierdzia okazuje stworzeniu niestrudzenie wyrozumiałość i przebaczenie. Niedoskonałość jest innym odcieniem niesamowystarczalności stworzenia (nikt poza Bogiem sam sobie nie zawdzięcza istnienia ani trwania przy życiu), jak również omylności poznawczej, chwiejności woli, podatności na irracjonalne bodźce (pokusy), licytujące się z porządkiem ustanowionym przez Stwórcę i zapisanym w sumieniu człowieka. Odpowiedzią na przejawy grzeszności człowieka, a jeszcze bardziej na świadome i dobrowolne decyzje i działania łamiące Boży porządek - dla których nie ma innego wyjaśnienia jak działanie pod wpływem przyczyny zewnętrznej („Wąż”) - jest według Objawienia przebaczenie pod warunkiem wszakże wyznania prawdy swego grzechu. Drugim warunkiem przebaczenia Bożego - równie istotnym - jest przebaczenie naszym „winowajcom”, to znaczy tym, którzy wobec nas zaciagnęli dług moralny, bo nas skrzywdzili, popełnili jakąś niesprawiedliwość, zadali ból, zgorszyli, pozbawili mienia czy dobrego imienia. Można przyjąć jako konkluzję, że niedoskonałość i grzeszność człowieka to duchowa przestrzeń, w której objawia się szczególny przymiot Boga - Jego miłosierdzie, skutkujące przebaczeniem wyjednanym przez ofiarę Jego Syna. Biblia to księga, w której prawda o Bogu przebaczającym przewija się jak złota nić od pierwszej do ostatniej jej strony.

\section{Forgiveness in the Bible (Summary)}

Forgiveness is a subject that runs through the Bible from its first to the last page with all the richness of its contents and dramatic indications. On one hand, it reaches the very foundations of the metaphysics of creation subject to "vanity"; on the other hand, it touches upon God who, using the wealth of his mercy, tirelessly 
shows understanding and forgiveness. According to the Revelation, God's answer to human sinfulness is forgiveness only if the sinner turns into the light of the truth concerning his sin. An equally important condition for being granted God's forgiveness is showing forgiveness to those who did us harm, committed injustice, inflicted pain, shocked, took something away, or damages our reputation. One may assume that human imperfection or sinfulness is a spiritual space where a special attribute of God manifests itself - his mercy which results in forgiveness coaxed thanks to his Son's sacrifice.

Key words: guilt; the truth of sin; forgiveness; mercy; understanding.

\section{Przebaczenie w Biblii (Streszcznie)}

Przebaczenie w Biblii jest tematem przewijającym się od pierwszej do ostatniej strony z całym bogactwem treści i dramatyzmem przejawów. Z jednej strony sięga samych podstaw metafizyki stworzenia poddanego „marności”, a z drugiej dotyka Boga, który w bogactwie swego miłosierdzia okazuje stworzeniu niestrudzenie wyrozumiałość i przebaczenie. Odpowiedzią Boga na grzeszność człowieka jest według Objawienia przebaczenie pod warunkiem, że grzesznik stanie w pełnym świetle prawdy swego grzechu. Warunkiem równie istotnym, aby dostapić Bożego przebaczenia, jest przebaczenie tym, którzy nas skrzywdzili, popełnili jakąś niesprawiedliwość, zadali ból, zgorszyli, pozbawili mienia czy dobrego imienia. Można przyjąć, że niedoskonałość i grzeszność człowieka to duchowa przestrzeń, w której objawia się szczególny przymiot Boga - Jego miłosierdzie, skutkujące wyjednanym przez ofiarę Jego Syna przebaczeniem.

Słowa kluczowe: wina; prawda grzechu; przebaczenie; miłosierdzie; wyrozumiałość.

\section{Bibliografia}

Chrostowski, Waldemar. „Anatomia pokusy (Rdz 3, 1-6)”. Przeglad Powszechny 5 (1984): 198-207.

Falkenroth, Udo. „Makrothymia“. W: Dizionario dei concetti biblilici del Nuovo Testamento, red. Lothar Coenen, Erich Beyreuther, Hans Bietenhard, 1228-1230. Bologna: Edizioni Dehoniane (EDB), 1976. 
Katechizm Kościoła katolickiego. Poznań: Pallottinum, 1994.

Lods, Marc. „Pardon”. W: Dictionnaire Encyclopedique de la Bible, red. Pierre-Mourice Bogaert i in., 967-968. Turnhout: Brepols, 1987.

Morris, Leon. „Przebaczenie”. W: Słownik teologii św. Pawła, red. Gerald F. Hawthorne, Ralph P. Martin, Daniel G. Reid, 661-663. Warszawa: Vocatio, 2010.

Papieska Komisja Biblijna. Natchnienie i prawda Pisma Świętego. Słowo, które od Boga pochodzi i mówi o Bogu, aby zbawić świat, tłum. Henryk Witczyk. Kielce: Verbum, 2014.

Popowski, Remigiusz. Wielki słownik grecko-polski Nowego Testamentu. Warszawa: Vocatio, 1995.

Potterie de la, Ignace. „Prawda”. W: Słownik teologii biblijnej, red. Xavier Léon-Dufour, 763-768. Poznań: Pallottinum, 1973.

The Oxford Dictionary of the Jewish Religion, red. R. J. Zwi Werblowsky, Geoffrey Wigoder. New York: Oxford University Press, 1997. 